\section{New Journal Editors}

\section{AMERICAN POLITICAL THOUGHT}

The American Political Thought Organized Section (Section 47) has announced Jeremy D. Bailey and Susan McWilliams as the next editors of American Political Thought: A Journal of Ideas, Institutions, and Culture. Nick Buccola will be the new book review editor of the journal. The new editors will serve for a four-year term, which began in summer 2019.

Jeremy D. Bailey is a professor in the Political Science Department and the Honors College at the University of Houston. His books include The Idea of Presidential Representation: An Intellectual and Political History (forthcoming from University Press of Kansas, 2019). Susan McWilliams is chair and professor of politics at Pomona College. She is most recently the author of The American Road Trip and American Political Thought (Lexington, 2018). Nick Buccola is the Elizabeth and Morris Glicksman Chair in Political Science at Linfield College. His next book, The Fire is Upon Us: James Baldwin, William F. Buckley Jr., and the Debate over Race in America, will be published by Princeton University Press in 2019.

Three editorial teams submitted proposals, and the decision was made by a selection committee comprised of Annette Gordon-Reed, Rogers Smith, Jeff Tulis, and Keith Whittington, as well as Section council members, Daniel Klinghard and George Thomas. American Political Thought is published quarterly by University of Chicago Press. Its current and founding editor is Michael Zuckert. The American Political Thought Section is grateful for Zuckert's work in founding the journal and for securing its strong position in the field.

\section{POLITICS \& GENDER}

Susan Franceschet, Professor of Political Science at the University of Calgary, and Christina Wolbrecht, Professor of Political Science at the University of Notre Dame, were appointed as editors to head the new Politics $\mathcal{E}$ Gender editorial team.

"We are delighted to have been selected as co-editors of Politics $\mathcal{E}$ Gender and are fully committed to maintaining the tradition of excellence established by our predecessors. We look forward to publishing the highest-quality research on gender and politics with a commitment to pluralism and diversity, including in terms of substantive topics, methodological approaches, and theoretical perspectives. Our vision for Politics $\mathcal{E}$ Gender understands gender as fundamental to and constitutive of politics, narrowly and broadly defined, in all contexts and arenas, and in all parts of the world. We view the study of gender and politics as necessarily intersectional and inclusive of issues of sexuality, sexual identity, and gender identity. We are excited to help facilitate continued scholarly advances in this dynamic and important field."

The new editors' term will begin July 2019 and be three years in duration. Their team includes Meryl Kenny (University of Edinburgh) as book review editor, and associate editors Sarah Bush (Yale University), Susanne Dovi (University of Arizona), Alice J. Kang (University of Nebraska), Diana Z. O'Brien (Texas A\&M), Wendy Smooth (Ohio State), and Pär Zetterberg (Uppsala University). The incoming editorial team and outgoing editor, Mary Caputi, Professor of Political Science at California State-Long Beach, are collaborating to make the transition as smooth as possible.

\section{Call for Submissions}

\section{RACIAL BIAS AND EQUITY: THE STATE OF THE DISCIPLINE}

Increasing the representation of historically underrepresented groups as well as recognizing the need to create space for the voices of intersectionally-situated scholars is a critical issue for the discipline of political science. This issue grows in importance as the United States, and especially the student population, only grows more diverse each year.

With this in mind, Ange-Marie Hancock Alfaro, University of Southern California, and Matthew Mendez Garcia, California State University Channel Islands, invite papers for a $P S$ symposium that together will facilitate a systematic and comprehensive analysis of racial diversity in the profession. Contributions are welcome from across the discipline to consider topics related to racial bias, racial equity, and the state of political science's engagement with this issue. Topics of interest may include but are not limited to:

- Citation politics

- Recruitment and retention

- Public intellectual and activist work

- Classroom incivility and free speech

- Equitable academic institutions

Please submit manuscript proposals by September 30, 2019 for full consideration to ps@apsanet.org. Questions regarding the symposium should be sent to Matthew at matthew.mendez@csuci.edu.. 